\title{
GAMBARAN KEJUJURAN SEBAGAI LANDASAN KEUTAMAAN MORAL MAHASISWA YANG SUDAH PERNAH MENGAMBIL MATA KULIAH CHARACTER BUILDING
}

\author{
Antonina Pantja Juni Wulandari \\ Jurusan Psikologi, Faculty of Humanities, BINUS University \\ Jl. Kemanggisan Ilir III No. 45. Kemanggisan-Palmerah, Jakarta barat 11480 \\ yunwulan@binus.edu
}

\begin{abstract}
This research sees an overview of honesty as the basis of students' moral virtue who had taken courses Character Building at Bina Nusantara University. An honest person is one who has the power of the heart goes to the rules and principles of righteous living. Gea, Wulandari, \& Babari (2002) conclude that if people have the virtue of honesty, they will not lie or cheat, even though they had the opportunity to do so. Moral virtue is a permanent and stable trend. Virtue is a good trait ingrained in one. The virtue relates to the will, as it relates to the will of the intent or motivation of the performer to be very important, so it is definitely virtuous behaviors with good intentions. The virtue is gained through the process of getting used to and practices. Virtue makes people be good personally (Bertens, 2002). By doing honest means the individual is said to have a moral virtue. The results were distributed to students who got the courses. From the results of the data on the questionnaire distributed to the students who got CB courses as 161 people, results of their honesty are not low. Most of the honesty they got was $61.7 \%$, while the highest honesty is $38.3 \%$.
\end{abstract}

Keywords: honesty, moral virtue, character building

\begin{abstract}
ABSTRAK
Penelitian ini melihat gambaran kejujuran sebagai landasan keutamaan moral mahasiswa yang sudah pernah mengambil mata kuliah character building di Universitas Bina Nusantara. Orang yang jujur adalah orang yang memiliki kekuatan hati berjalan pada aturan dan prinsip hidup yang benar. Gea, Wulandari, \& Babari (2002) menyimpulkan bahwa kalau orang memiliki keutamaan kejujuran, maka orang itu tidak akan berbohong atau menipu, walau sebenarnya dia memiliki kesempatan untuk melakukannya. Keutamaan moral adalah suatu kecenderungan tetap dan stabil. Keutamaan adalah sifat baik yang sudah mendarah daging pada seorang. Keutamaan berkaitan dengan kehendak, karena berkaitan dengan kehendak maka maksud atau motivasi si pelaku menjadi sangat penting, jadi perilaku berkeutamaan pasti disertai maksud baik. Keutamaan diperoleh melalui jalan membiasakan diri dan proses latihan. Keutamaan membuat manusia menjadi baik secara pribadi (Bertens, 2002). Dengan berbuat jujur bearti individu dikatakan mempunyai keutamaan moral. Hasil penelitian yang yang dibagikan pada mahasiswa yang sudah mendapat mata kuliah. Dari hasil olah data pada kuesioner yang dibagikan pada mahasiswa yang sudah mendapat mata kuliah CB sebanyak 161 orang, terlihat hasil kejujuran mereka tidak ada yang rendah. Terbanyak adalah kejujuran mereka sedang yaitu 61,7\%, sedangkan kejujuran tertinggi ada sebanyak 38,3\%
\end{abstract}

Kata kunci: kejujuran, keutamaan moral, character building 


\section{PENDAHULUAN}

Kejujuran bukanlah sebuah benda yang biasa yang sering kita lihat dan sentuh, ia tak yang mudah digenggam erat sepanjang hidup. Karena memang kita sering mengangapnya sebagai sesuatu dengan penuh risiko. Banyak orang yang menggunakan berbagai cara untuk mencapai apa yang diinginkannya meski melepaskan kejujuran dari genggamannya. Kejujuran tetaplah kejujuran yang tak dapat disejajarkan dengan nilai materi beberapa juga karena memang ia tak mengenal untung-rugi. Ia bagaikan mutiara yang bersinar meski terlindas kejamnya peradapan manusia. Kejujuran adalah dasar dari kepercayaan, dan kepercayaan merupakan dasar dari suatu hubungan (Schiller \& Bryant, 2002). Kejujuran memang mudah terucap, tetapi sulit dilakukan. Sekali orang tidak jujur, sulit baginya mendapat kepercayaan,

Simorangkir (1992) mengatakan kita wajib berusaha dengan tekun mencari jalan yang benar, kendati keterbatasan kita dalam menentukan jalan yang benar. Walaupun kita sering mengalami kesukaran dalam memutuskan apa yang baik, kita harus berusaha mencapai keputusan yang benar. Di tengah kondisi dan keadaan yang rumit, tetap memilih keputusan yang etis. Kejujuran adalah karakter. Santrock (2008) menyebutkan karakter bukan sekadar hasil dari sebuah tindakan melainkan secara simultan merupakan hasil dan proses.

Kalau kita lihat kondisi negara kita yang sedang terpuruk, tidak selalu membutuhkan orangorang pintar, karena mereka yang pintar bisa jadi akan menipu rakyat dengan kepintarannya. Karena itu diperlukan pemimpin yang berkarakter baik dan memiliki rasa kemanusiaan yang mencintai rakyat terutama yang miskin (Willis, 2005). Jadi pendidikan di sini masih membutuhkan pendidikan yang mengarahkan pada pembangunan karakter, agar dapat menciptakan generasi muda yang tidak saja pintar tetapi juga menjadikannya seseorang berkarakter baik luar dan dalam (secara fisik atau mental) atau dengan kata lain menjadi Good harus pendidikan itu mengarah kepada education of heart, tujuannya adalah agar orang bukan hanya dapat tetapi juga mempunyai keinginan untuk memberi dan menerima kasih. Menanggapi pentingnya adanya pendidikan yang mengarah pada pembangunan karakter anak didik, maka salah satu universitas di Jakarta yaitu Universitas Bina Nusantara mulai menerapkan mata kuliah Character Building (CB) pada tahun 2002. Mata kuliah ini menjadi mata kuliah wajib yang harus diambil dan menggantikan mata kuliah dasar umum. Maksud diadakannya mata kuliah ini adalah untuk menyiapkan sumber daya manusia yang tidak saja memiliki kemampuan akademik tinggi (“Smart”), melainkan juga memiliki watak yang baik (“Good”).

Semuanya ini menjadi satu kesatuan sehingga menghasilkan sarjana yang bermutu, baik dari segi kemampuan maupun watak. Dengan melihat latar belakang tersebut dan terutama adanya mata kuliah CB di UBiNus, peneliti ingin mengetahui apakah mahasiswa yang sudah menerima mata kuliah CB karakternya menjadi lebih baik, terutama dalam hal kejujuran.

\section{Tinjauan Teoretis}

Orang yang jujur adalah orang yang memiliki kekuatan hati berjalan pada aturan dan prinsip hidup yang benar. Gea, Wulandari, \& Babari (2002) menyimpulkan bahwa kalau orang memiliki keutamaan kejujuran, orang itu tidak akan berbohong atau menipu walau sebenarnya dia memiliki kesempatan untuk melakukannya. Keluruhuran manusia berakar dalam kenyataan bahwa ia berakalbudi. Menurut Suseno (1999), akal budi berarti bahwa hati dan wawasan manusia merentangkan diri mengatasi segala keterbatasan ke arah cakrawala yang tak terbatas. Karena jangkauannya itu, ia tidak terikat pada satu titik. Oleh karena itu, ia dapat berhadapan dengan manusia lain dan alam secara sadar, ia terbuka pada seluruh realitas. 
Tidak mudah dan sering sukar mengambil suatu keputusan etis, orang yang setuju tentang prinsip etis belum tentu setuju dengan penerapan prinsip itu di dalam suatu kasus nyata tertentu. Contoh seorang pengusaha setuju dengan larangan berbohong, namun tidak keberatan memberikan uang pelicin kepada pejabat untuk memperoleh fasilitas usaha. Bagi dia tidak menjadi masalah, entah itu bertentanagan dengan peraturan atau tidak (Simorangkir, 1992).

Tahap perkembangan moral Kohlberg (Santrock, 2008): pertama, prakonvensional: perhatian untuk akibat perbuatan (hukuman, ganjaran, motof-motif lahiriah dan partikular. Kedua, konvensional: perhatian untuk maksud perbuatan (memenuhi harapan, mempertahankan ketertiban). Ketiga, pascakonvensional: hidup moral adalah tanggung jawab pribadi atas dasar prinsip-prinsip batin (maksud dan akibat-akibat tidak diabaikan / motif-motif batin dan universal).

Orang yang jujur adalah orang yang memiliki integritas. Integritas adalah suatu sifat dasar yang dimiliki seseorang yang utuh dalam arti bahwa kepribadiannya tidak berkotak-kotak melainkan bahwa ia bersikap dan bertindak sebagai dirinya sendiri, konsekuen dan sama dari perbagai dimensi kehidupan menurut suatu pola kepribadian yang tidak memaksa untuk terus menerus menyembunyikan wajahnya yang sebenarnya. Jadi orang yang memiliki integrasi batinnya kuat, ia akan satu dalam sikap hati dan tindakan, orang tersebut akan bohong, janjinya akan dapat dipercaya (Suseno, 1992).

Keutamaan moral adalah suatu kecenderungan tetap dan stabil. Keutamaan adalah sifat baik yang sudah mendarah daging pada seorang. Keutamaan berkaitan dengan kehendak, karena berkaitan dengan kehendak maka maksud atau motivasi si pelaku menjadi sangat penting, jadi perilaku berkeutamaan pasti disertai maksud baik. Keutamaan diperoleh melalui jalan membiasakan diri dan proses latihan. Keutamaan membuat manusia menjadi baik secara pribadi (Bertens, 2002).

Keutamaan moral menurut Adam Smith (dalam Soemardjan, 2000) adalah menyangkut watak yang unggul. Watak yang unggul ini hanya bisa diketahui dengan kemampuan perasaan moral, yaitu dengan simpati dari masyarakat tak berpihak. Dengan kata lain keutamaan adalah watak yang dibenarkan dan dipuji atas dasar simpati dari masyarakat yang tak berpihak. Jadi keutamaan moral adalah: "Kualitas moral yang menyebabkan suatu tindakan dibenarkan dan dipuji dalam penilaian moral."

Keutamaan moral berkaitan dengan tindakan atau perilaku yang pantas dikagumi dan disanjung. Tindakan yang mengandung keutamaan pantas dikagumi karena tindakan tersebut benarbenar hebat, luar biasa dan mengagumkan. Tindakan seperti itu berada pada tataran yang jauh melampaui tataran tindakan yang vulgar dan biasa. Karena itu, keutamaan berarti excellence (sesuatu yang unggul dan mengagumkan) atau suatu kualitas yag luar biasa.

Keutamaan pantas dikagumi sedangkan kepantasan moral hanya pantas untuk disetujui dan dibenarkan. Kepantasan moral adalah sesuatu yang biasa saja, sedangkan keutamaan moral adalah sesuatu yang luar biasa. Sementara kepantasan moral menimbulkan pujian, keutamaan moral menimbulkan perasaan bahwa memang hal itu pantas dipuji (praise-worthy). Keutamaan adalah kualitas yang dicintai dan dikagumi oleh masyarakat tak berpihak. Dengan kata lain, keutamaan moral adalah kualitas yang akan selalu dikagumi dan pantas dipuji oleh masyarakat dan manusia pada umumnya (Suseno, 1999).

Cirinya yang pantas dipuji dan luar biasa ini terletak dalam kenyataan bahwa orang yang memiliki keutamaan moral tidak hanya bertindak sekedar mengikuti aturan. Ia mengikuti aturan bukan karena ia harus melakukan ini dan itu, melainkan karena ia sendiri memiliki perasaan moral akan nilainilai moral tertentu. Maka, orang yang bertindak berdasarkan keutamaan moral bahkan tidak peduli apakah ia memang diwajibkan begini atau begitu. 
Keutamaan-keutamaan moral pokok menurut Smith (dalam Soemardjan, 2000) adalah: pertama, beneficience (berbuat baik bagi orang lain) tertuju untuk orang lain. Keutaman moral ini didasarkan pada kemauan untuk membahagiakan orang lain. Kedua, prudence (berbuat baik yang ditujukan untuk diri sendiri). Keutaman ini adalah kearifan jenis khusus yang digambarkan Smith "Sebagai keadaan batin yang waspada, jeli dan sangat hati-hati, selalu penuh perhatian terhadap konsekuensi-konsekuensi yang paling jauh dari setiap tindakan untuk memperoleh kebaikan yang paling besar dan untuk menghindar dari kejahatan yang paling besar.” Ketiga, keadilan (keutamaan yang ditujukan pada orang lain maupun pada diri sendiri). Secara khusus prinsip ini mengacu pada sikap menahan diri untuk tidak merugikan orang lain. Kita dianggap bertindak adil terhadap sesama kita kalau kita menahan diri untuk tidak merugikannya dan secara tidak langsung melukainya, entah menyangkut pribadi, miliknya atau reputasinya.” Bertindak adil terhadap orang lain, kalau kita tidak melukai atau merugikannya entah sebagai manusia, sebagai anggota sebuah keluarga atau sebagai warga sebuah masyarakat. Keempat, pengendalian diri (self-comand); selain keutamaan-keutamaan pokok tadi, manusia bisa bertindak sesuai keutamaan tadi dibutuhkan keutamaan khusus, yaitu pengendalian diri (self-comand). Pengendalian diri bukanlah keutamaan yang biasa melainkan sebuah meta-keutamaan (meta-vertue): "Pengendalian diri tidak hanya merupakan keutamaan paling besar, tetapijuga dari keutamaan ini semua keutamaan yang lain memperoleh kecemerlangan yang utama". Pengendalian diri adalah suatu keutamaan yang tertinggi dan kearifan istimewa yang memungkinkan manusia benar-benar bertindak sesuai dengan keutamaan.

Smith (dalam Soemardjan, 2000) sadar bahwa tidak semua orang bisa mempunyai watak seperti itu. Karena itu, ia membedakan antara keutamaan yang biasa dan keutamaan yang luar biasa. Yang disebut terakhir adalah keutamaan yang sempurna. Yang pertama hanya mendekati yang sempurna. Menurut Smith, keutamaan yang biasa itulah yang bisa dicapai oleh sebagian besar manusia.

\section{Mata kuliah Character Building}

Mata kuliah Character Building (disingkat CB) merupakan mata kuliah baru yang pertama kali diajarkan di Universitas Bina Nusantara, mulai semester ganjil 2002/2003. Pengadaan mata kuliah ini merupakan suatu upaya menghadapi tantangan masa depan yang makin meningkat kompetisinya serta makin bersifat global, maka perlu mempersiapkan sumber daya manusia yang tidak saja memiliki kemampuan akademik tinggi ("Smart") melainkan juga memiliki watak yang baik ("Good"). Watak itu tercermin dalam tindakannya yang mampu memberikan jiwa dan raganya demi kepentingan dan nilai yang lebih tinggi, yang mengatasi keterkungkungan individu.

Mata kuliah CB merupakan yang dirancang khusus untuk membantu mahasiswa mendalami nilai-nilai kemanusiaan. Inti sari mata kuliah ini adalah merupakan keseluruhan dinamika relasional antarpribadi dengan berbagai macam dimensi, baik dari dalam maupun dari luar dirinya, agar pribadi itu semakin dapat menghayati kebebasannya, sehingga ia dapat semakin bertanggung jawab atas pertumbuhan dirinya sebagai pribadi dan perkembangan orang lain dalam hidup mereka.

Mata kuliah ini terdiri dari empat bagian yaitu: Character Building I; membantu mahasiswa agar dapat membuat penilaian tentang dirinya sendiri baik kelemahan serta kekuatannya, sehingga diharapkan dapat mengembangkan diri dengan tepat. Character Building II; membantu mahasiswa mampu menunjukkan sikap dan perilaku baik dan wajar dalam kehidupan bersama, dengan menjunjung tinggi nilai-nilai sosial yang berlaku sehingga suasana hidup damai dan tentram dapat terwujud dan terpelihara dengan baik. Character Building III; membantu para mahasiswa agar semakin mampu menemukan gambaran yang semakin baik tentang Tuhan, mau membangun hubungan yang semakin dekat dengan Tuhan melalui keterlibatan aktif merayakan ritual keagamaan, mau menghayati iman dalam kehidupan nyata terutama dengan berusaha hidup sesuai dengan ajaranajaran Tuhan, serta mau saling menghormati dan bekerjasama dengan pemeluk agama lain untuk membangun dunia yang semakin manusiawi. Character Building IV; membantu mahasiswa agar mau 
dan mampu menunjukkan sikap dan perilaku bertanggung jawab (terutama secara moral) terhadap pelestarian lingkungan hidup, penerapan dan pengembangan ilmu pengetahuan dan teknologi serta penghayatan prinsip-prinsip etis dalam menjalankan profesi.

Dengan melihat cakupan yang cukup luas ini maka materi kuliah CB disajikan dalam empat semester, dengan beban SKS masing-masing mata kuliah CB adalah 2 SKS. Dosen membantu mahasiswa secara aktif mengkonstruksikan pemahaman mereka, dengan memecahkan masalah melalui jalan yang akan membawa ke pemecahan soal, berpikir kritis untuk untuk menentukan suatu dilema moral. Materi ada yang disajikan dalam bentuk multimedia dan mempergunakan Learning Management System (LMS) yang dirancang untuk menampilkan bahan pembelajaran lewat web, tempat berdiskusi antara dosen dan mahasiswa, atau antarmahasiswa.

\section{METODE PENELITIAN}

Subjek dari penelitian ini adalah mahasiswa Universitas Bina Nusantara yang sedang mengambil mata kuliah Character Building IV. Karakteristik subjek adalah seorang individu yang sedang memasuki masa remaja "Remaja lanjut” yang menuju taraf kedewasaan. Berumur berkisar 2123 tahun dan pernah mengikuti mata kuliah CB I, CB II, CB III, jadi mereka adalah mahasiswa semester 7 ke atas. Mata kuliah CB merupakan mata kuliah prasyarat, maksudnya mahasiswa yang mengambil CB I harus mengambil mata kuliah CB II terlebih dahulu. Begitu pula bagi yang hendak mengambil mata kuliah CB IV harus pernah mengambil mata kuliah CB I, CB II, dan. CB III. Oleh karena itu, dalam penelitian ini sampel yang akan diambil dari mahasiswa yang sedang mengambil mata kuliah CB IV dengan alasan bahwa mahasiswa itu sudah pernah mengambil mata kuliah CB yang lainnya. Dengan demikian diharapkan lebih bisa menggambarkan hasil pembelajaran CB. Jumlah sampel heterogen dari beberapa fakultas, maka teknik pengambilan sampel menggunakan Simple random Sampling. Dengan menggunakan teknik tersebut maka sampel yang diambil 161 mahasiswa.

Dalam penelitian ini digunakan metode penelitian kuantitatif non-eksperimental. Dalam proses pengambilan data dilakukan di Universitas Bina Nusantara, Jakarta. Proses pengambilan data akan dilakukan pada waktu mahasiwa yang mengambil mata kuliah CB IV Instrumen alat ukur yang digunakan berupa kuesioner yang dibuat oleh CBDC (Character Building Development Center), dengan pertanyaan-pertanyaan yang akan dipakai untuk mengukur tentang tingkat kejujuran mahasiswa. Maka dari itu, akan dipakai Skala Likert, skala ini terdiri dari 5 pilihan jawaban yaitu: selalu dilakukan, sering dilakukan, kadang-kadang dilakukan, jarang dilakukan, tidak pernah dilakukan. Penilaian yang digunakan untuk mengukur skala adalah jawaban 5: selalu dilakukan, 4: sering dilakukan, 3: kadang-kadang dilakukan, 2: jarang dilakukan, 1: tidak pernah dilakukan.

\section{HASIL DAN PEMBAHASAN}

Dari hasil olah data pada kuesioner yang dibagikan pada mahasiswa yang sudah mendapat mata kuliah CB sebanyak 161 orang, terlihat hasil kejujuran mereka tidak ada yang rendah. Terbanyak adalah kejujuran mereka sedang yaitu 61,7\%, sedangkan kejujuran tertinggi ada sebanyak 38,3\%. Perhatikan gambar diagram 1. 


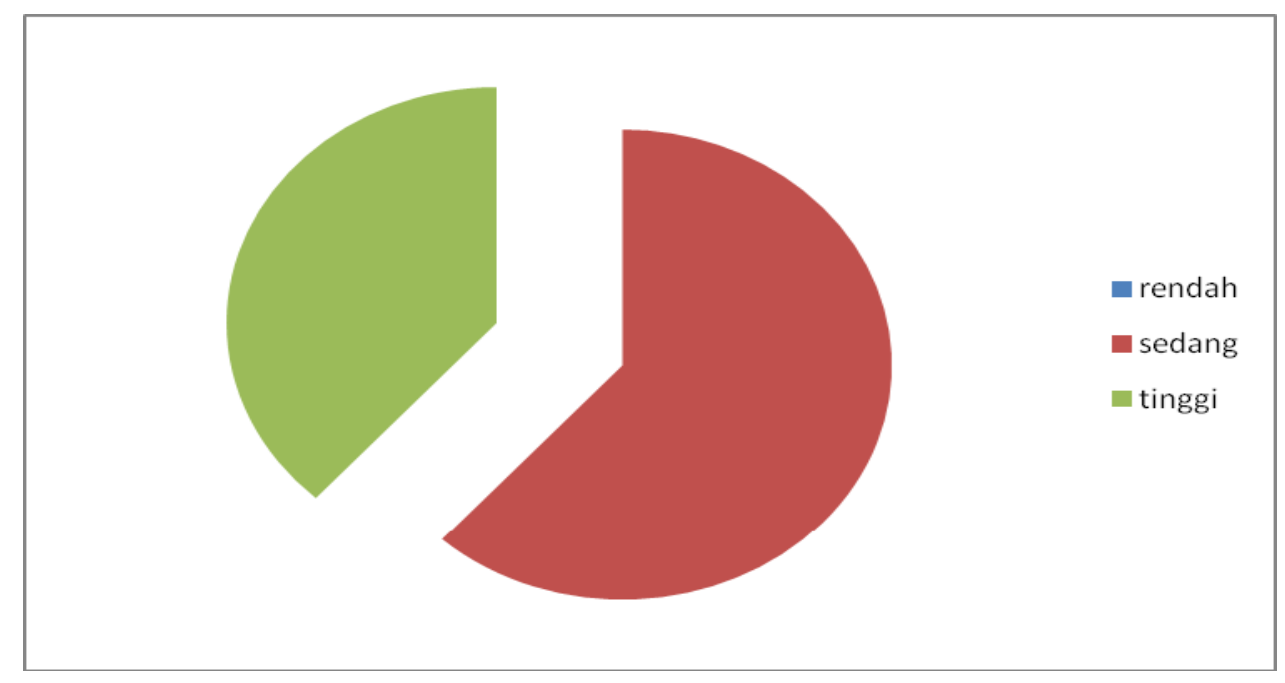

Gambar 1 Gambaran Kejujuran Mahasiswa yang Sudah Mengambil Mata kuliah CB

Dari hasil olah data tersebut rata-rata mahasiswa yang sudah mengikuti mata kuliah CB I, CB II, dan CB III tingkat kejujurannya adalah sedang. Kemungkinannya mata kuliah CB tersebut dapat meningkatkan kejujuran mahasiswa, atau kemungkinan yang lain adalah proses pola asuh dari orang tua. Tahap perkembangan moral mereka menurut Kohlberg pada taraf pascakonvensional yaitu hidup moral adalah tanggung jawab pribadi. Manusia yang mempunyai keutamaan moral memilik watak yang baik, maksudnya ialah manusia yang dalam tindakannya selalu memilih yang baik sesuai dengan penerangan budinya. Disebut juga manusia yang susila maksudnya yang bertindak menurut kemanusiaanya yang selalu memilih tindakan yang menurut keyakinannya (penerangan budinya) adalah baik.

Dalam praktik memang tidak mudah mencapai watak yang baik ini harus ada kehendak untuk mewujudkannya. Setiap manusia memiliki daya untuk memilih yang disebut dengan kehendak atau istilahnya disebut dengan kehendak bebas. Ini merupakan suatu aspek kemanusiaannya. Untuk memilih, manusia harus tahu apa yang dipilihnya. Tidak mungkin orang benar-benar mau kalau ia tidak tahu, kalau ia tidak tahu. Mau dan tahu tak mungkin dapat dipisahkan. Daya untuk tahu itulah yang disebut akal atau budi. Orang tahu atau mempunyai pengetahuan tentang sesuatu ialah jika ia mengatakan sesuatu tentang sesuatu itu. Tahu juga bisa menghubungkan sesuatu dengan fakta (realitas). Cita-cita manusia dalam tahunya ialah mencapai kebenaran, tak seorang pun cinta pada kekeliruan. Objek tahu sebenarnya adalah kebenaran. Jadi orang tahu bahwa pengetahuannya itu tidak benar, maka diusahakannya, supaya ia mencapai kebenarannya, melainkan mungkin mencoba hendak mengetahui seluruh objeknya dengan segala macam aspeknya.

Dengan adanya pengetahuan mana yang baik itu dan mana yang buruk serta selalu didorong untuk melakukan yang baik itu, manusia pasti mempunyai keutamaan moral/watak yang baik. Adanya kehendak memilih, sering membuat langkah ke arah menjadi yang baik. Ini pergulatan dan peperangan, dan tidak jarang manusia mengalami kekalahan dalam peperangan. Manusia susila ialah manusia yang bertingkah laku baik. Ia bertanggung jawab terhadap kata hatinya karena ia selalu memilih menurut petunjuk kata hati tersebut. Ia juga bertanggung jawab kepada siapa pun yang berhak menuntut jawab perbuatannya. Ia berkepribadian: satu-satunya pedoman bagi tingkah lakunya ialah keyakinan bahwa itu baik. Dengan demikian ia tak terombang-ambing oleh apapun dalam pendirian etis. 


\section{SIMPULAN}

Subjek penelitian pada kelompok mahasiswa yang sudah mengikuti mata kuliah CB I, CB II, dan CB III. Subjek penelitian pada kelompok mahasiswa yang sudah mengikuti mata kuliah CB ratarata berumur $17 \mathrm{~s} / \mathrm{d} 20$ tahun. Dari hasil olah data pada kuesioner yang dibagikan pada mahasiswa yang sudah mendapat mata kuliah CB sebanyak 161 orang, terlihat hasil kejujuran mereka tidak ada yang rendah. Terbanyak adalah kejujuran mereka sedang yaitu $61,7 \%$, sedangkan kejujuran tertinggi ada sebanyak 38,3\%. Penelitian ini hanyalah salah satu usaha untuk melihat gambaran kejujuran sebagai landasan keutamaan moral mahasiswa yang sudah pernah mengambil mata kuliah CB. Untuk penelitian lanjut bisa dipakai alat ukur yang lain, sehingga mungkin dapat hasil yang mungkin berbeda atau mungkin sama. Kejujuran sangat erat hubungannya dengan keutamaan moral mahasiswa sehingga boleh dikatakan mempunyai peran yang penting dalam pembentukan karakter. Mata kuliah CB adalah pembentukan karakter, maka diskusi-diskusi tentang dilema moral perlu diperbanyak karena sesuai dengan taraf perkembangan moral mahasiswa yang sudah sampai pada tarap pascakonvensional, hidup moralnya sudah menjadi tanggung jawab pribadi.

\section{DAFTAR PUSTAKA}

Bertens. (2002). Etika. Jakarta: Gramedia.

Keller, S. (1995). Penguasa dan Kelompok Pemimpin: Peranan Pemimpin Penentu dalam Masyarakat Modern. Penerjemah Zahara D. Noer. Jakarta: Raja Grafindo Persada.

Keraf, A. S. (1996). Pasar Bebas Keadilan \& Peran Pemerintah. Yogyakarta: Kanisius.

Santrock, J. W. (2008). Educational Psychology (3 ${ }^{\text {th }}$ ed.). Boston: Mc Graw Hill.

Schiller, P., \& Bryant, T. (2002). 16 Nilai Moral Dasar Bagi Anak. Penerjemah Susi Sensusi. Jakarta: Elex.

Simorangkir, O.P. (1992). Etika Bisnis. Aksara Persada Indonesia.

Soemardjan, S. (2000). Menuju Tata Indonesia Baru. Jakarta: Gramedia.

Suseno, F. M. (1992). Berfilsafat dari konteks, Jakarta: Gramedia Pustaka Utama. . (1999). Kuasa dan Moral, Jakarta: Gramedia Pustaka Utama. 